\title{
Pembelajaran Matematika Realistik
}

\author{
Emy Sohilait \\ Program Studi Pendidikan Matematika, STKIP Gotong Royong Masohi, Jl Trans Seram Belakang \\ Negeri haruru, Maluku Tengah, 97514 Indonesia \\ e-mail: sohilaitemy@gmail.com;Tel.: +682399221490
}

\begin{abstract}
Abstrak:
Objek yang ada dalam matermatika bersifat abstrak. Karena sifatnya yang abstrak, tidak jarang guru maupun siswa mengalami beberapa kendala dalam proses pembelajaran. Untuk mengurangi tingkat keabstrakan siswa terhadap matematika, saat ini sudah dikenalkan dengan pendekatan Pembelajaran Matematika Realistik (PMR). PMR lebih mendekatkan matematika dengan lingkungan siswa. Dalam pendekatan PMR guru harus mengaitkan atau menghubungkan konsep-konsep matematika dengan pengalaman siswa dalam kehidupan sehari-hari dan menerapkan kembali konsep matermatika yang telah dimiliki siswa pada kehidupan sehari-hari. Tujuan artikel ini adalah memaparkan tentang pembelajaran matematika realistik. Metode yang digunakan adalah kajian literatur.
\end{abstract}

Kata Kunci: pembelajaran matematika realistik

\section{Realistic Mathematics Education}

\begin{abstract}
:
Teachers and students experience several obstacles in the learning process. In order to reduce the level of students' abstractness towards the materials, currently it has been introduced to the Realistic Mathematics Education (RME) approach. RME brings mathematics closer to the student environment. In the RME approach, the teacher must link or relate mathematical concepts to students' experiences in everyday life and re-apply the material concepts that students already have in everyday life. The purpose of this article is to describe realistic mathematics learning. The method used is literature review.
\end{abstract}

Keywords: realistic mathematics education

\section{Pendahuluan}

Matematika merupakan salah satu pelajaran yang diberikan mulai dari tingkat dasar sampai perguruan tinggi. Objek yang ada dalam matematika bersifat abstrak. Karena sifatnya yang abstrak, tidak jarang guru maupun siswa mengalami beberapa kendala dalam proses pembelajaran. Proses pembelajaran matematika di sekolah belum dianggap sebagai aktivitas yang menyenangkan. Padahal dalam kehidupan sehari-hari tidak dapat dipungkiri terdapat aktivitas manusia yang berhubungan dengan matematika. Soedjadi, Price, dan Zamroni (Wahyudi, 2012, p. 1) mengatakan bahwa mengaitkan pengalaman kehidupan nyata dengan ide-ide matematika dalam pembelajaran di kelas sangat penting dilakukan agar pembelajaran bermakna sehingga siswa lebih menikmati. Menurut (Heuvel-Panhuizen, 2000, p. 5) bila anak belajar matematika terpisah dari pengalaman sehari-hari maka menjadi cepat lupa dan tidak dapat mengaplikasikan matematika dalam kehidupannya. Berdasarkan pendapat di atas, pembelajaran matematika sebaiknya ditekankan pada keterkaitan antara konsepkonsep matematika dengan pengalaman sehari-hari. Selain itu, perlu menerapkan kembali konsep matematika yang telah dimiliki anak pada kehidupan sehari-hari atau pada bidang lain yang terkait. Adalah seorang ahli psikologi (Freudenthal, 2006) yang memperkenalkan suatu pendekatan Pembelajaran Matematika Realistik (PMR) atau disebut juga Realistic Mathematics Education (RME) merupakan teori pembelajaran matematika yang berorientasi pada matematisasi pengalaman seharihari (mathematize of everyday experience) dan menerapkan matematika dalam kehidupan sehari-hari. 
Pembelajaran ini pertama kali dikembangkan dan dilaksanakan di Belanda dan berhasil memudahkan siswa untuk belajar matematika. Oleh karena itu, penulis mencoba membahas pendekatan PMR pada kajian teori ini dengan harapan dapat memberikan gambaran proses pembelajaran dengan menggunakan pendekatan matematika realistik. Adapun permasalahan yang akan dibahas dalam artike ini adalah sebagai berikut.

1) Bagaimana prinsip-prinsip yang digunakan dalam pendekatan PMR?

2) Bagaimana karakteristik dalam pendekatan PMR?

3) Bagaimana langkah-langkah pada pendekatan PMR?

4) Apa saja kelebihan dan kekurangan pada pendekatan PMR?

5) Teori-teori apa yang digunakan dalam mendukung pembelajaran matematika realistik?

\section{Metode}

Metode penelitian yang dilakukan penulis merupakan kajian literatur, yaitu penelitian yang dilakukan hanya berdasarkan karya tulis, seperti buku, jurnal, dan referensi lainnya. Penulis mengumpulkan referensi yang relevan yang berkaitan dengan pendekatan Pembelajaran Matematika Realistik (PMR).

\section{Kajian Teori}

\subsection{Pembelajaran Matematika Realistik}

\subsubsection{Sejarah Pembelajaran Matematika Realistik}

Realistic Mathematics Education (RME) merupakan teori pembelajaran khusus matematik yang dikembangkan pertama kali di negeri Belanda, tepatnya di the Freudenthal Institute, Utrecht University, sejak tahun 1970an oleh Freudenthal (Al Jupri, 1998, p. 86) . Permulaan munculnya teori RME adalah sejak proyek Wiskobas (matematika di sekolah dasar) tahun 1968 yang digagas Edu Wijdeveld dan Fred Goffree, kemudian bergabung Adri Treffers. Ketiga ahli pendidikan matematika inilah yang pertama kali mengembangkan dasar-dasar dari teori RME.

Tahun 1971, ketika proyek Wiskobas menjadi bagian institut IOWO, dengan Hans Freudenthal sebagai direktur utama, dan tahun 1973 ketika institute IOWO mengembangkan proyek Wiskivon untuk pendidikan matematika sekolah menengah, maka hal inilah yang menjadi dasar permulaan dalam mereformasi pendekatan pembelajaran matematika yang sebelumnya telah lama digunakan di Belanda (Van den Heuvel-Panhuizen \& Drijvers, 2014, p. 551). Pendekatan yang sebelumnya digunakan di Belanda adalah pendekatan mekanistik, yakni matematika diajarkan secara langsung pada tahap formal, terpisah antar topik, dan konten matematika disusun berdasarkan struktur matematika sebagai suatu disiplin ilmiah. Siswa belajar matematika dengan cara mempelajari prosedur selangkah demi selangkah mengikuti demonstrasi dan contoh guru dalam menyelesaikan masalah matematika. Hal ini mengakibatkan matematika sebagai pengetahuan kaku yang bersifat reproduktif. Sebagai alternatif dari pendekatan mekanistik ini, matematika modern yang kala itu sedang tren di dunia hampir saja mempengaruhi negeri Belanda. Untung saja, Freudenthal dengan timnya mampu membendung masuknya pendekatan matematika modern ke Belanda, dan sebagai alternatifnya pendekatan RME berkembang hingga kini dan seterusnya.

Karena institut IOWO dipimpin Freudenthal pada tahun 1991 dinamai Freudenthal Institute, merupakan institut untuk mereformasi pendidikan matematika di Belanda di bawah naungan Utrecht University, teori RME banyak dipengaruhi gagasan Freudenthal (Al Jupri, 1998, p. 86). Menurut Freudenthal gagasan pokok teori RME ini hendaknya matematika matematika diperkenalkan sebagai pengetahuan yang bermakna bagi siswa, dan matematika itu merupakan aktivitas manusia. Oleh karena itu, dalam proses pembelajaran, matematika bukan dipelajari sebagai sistem tertutup, melainkan harus dipelajari sebagai suatu aktivitas mematematisasi realitas dan mematematisasi matematika itu sendiri. 
Menurut Van den Heuvel-Panhuizen dan Drijvers (Al Jupri, 1998, p. 86), gagasan matematis horizontal dan vertikal dalam proses bermatematika yang semula digagas oleh Treffers diambil alih dan disempurnakan oleh Freudenthal. Dalam matematisasi horizontal, siswa menggunakan matematika untuk mentransformasi situasi masalah realistik ke dalam situasi matematis dalam bentuk model matematika; dan dalam matematisasi vertikal, siswa bekerja dalam dunia matematika melalui proses reorganisasi model hingga ditemukan penyelesaian masalah.

Beberapa kegiatan dalam matematisasi horizontal menurut Turmudi (Rahmawati, 2013, p. 4) yaitu:

1. Pengidentifikasian matematika khusus dalam konteks umum

2. Pensekemaan

3. Perumusan dan penvisualan masalah dalam cara yang berbeda

4. Penemuan relasi (hubungan)

5. Penemuan keteraturan

6. Pengenalan aspek isomorfic dalam masalah-masalah yang berbeda

7. Pentransferan real worl problem ke dalam mathematical problem

8. Pentransferan real worl problem ke dalam suatu model matematika yang diketahui.

Sedangkan beberapa kegiatan matematisasi vertikal menurut Turmudi (Rahmawati, 2013,

p. 4) yaitu:

1. Menyatakan suatu hubungan dalam suatu rumus

2. Membuktian keteraturan

3. Perbaikan dan penyesuaian model

4. Penggunaan model-model yang berbeda

5. Pengkombinasian dan pengintegrasian model-model

6. Perumusan suatu konsep matematika baru

7. Penggeneralisasian.

Hal lain yang perlu dipahami tentang RME adalah istilah tentang "realistic" yang berasal dari istilah bahasa Belanda "zich REALISEren" yang bermakna "untuk dibayangkan". Dengan demikian, kata "realistic" bisa bermakna: (1) konteks nyata yang ada dalam kehidupan sehari-hari; (2) konteks matematis formal dalam dunia matematika; atau (3) konteks hayalan yang tak terdapat dalam kenyataan tetapi dapat dibayangkan. Sementara De Lange (Rahmawati, 2013, p. 3) mendefinisikan dunia nyata sebagai suatu dunia nyata yang konkrit, yang disampaikan kepada siswa melalui aplikasi matematika. Begitulah cara kita memahami proses belajar matematika yangterjadi pada siswa, yaitu terjadi pada situasi nyata. Proses pengembangan konsep dan ide matematika dimulai dari dunia real oleh De Lange (Rahmawati, 2013, p. 3) disebut "matematisasi konsep". Freudenthal, Van den Heuvel-Panhuizen; van den Heuvel-Panhuizen \& Drijvers (Al Jupri, 1998, p. 87) menyatakn bahwa ketiga makna ini dipandang sebagai arti istilah "realistic" asalkan konteks-konteks tersebut dapat dibayangkan di dalam pikiran siswa yang sedang belajar matematika.

Dengan demikian dapat disimpulkan bahwan pendidikan matematika realistik adalah pendekatan pembelajaran yang mengaitkan kehidupan siswa dengan materi pelajaran sehingga memudahkan siswa dalam memahami konsep pembelajaran matematika.

\subsubsection{Prinsip-prinsip Pembelajaran Matematika Realistik (PMR)}

Secara operasional istilah "Pendidikan Matematika Realistik (PMR)" sering pula disebut "Pembelajaran Matematika Realistik (PMR)". Oleh karena itu kedua istilah tersbut dapat digunakan dengan makna yang sama. Menurut Gravemeijer (Afriansyah, 2016, p. 3) terdapat tida prinsip dalam mendesain pembelajaran pembelajaran dengan pendekatan PMR yaitu: 
1. Penemuan kembali dan permatematikaan progresif (guided reinvention and progressive mathematizing)

Dalam pembelajaran matematika, siswa hendaknya diberikan kesempatan untuk menemukan ide matematika melalui proses belajar. Pemikiran informal dapat menginspirasi pemikiran siswa sebagai pendahuluan ke prosedur yang lebih formal. Upaya ini akan tercapai jika pengajaran yang dilakukan menggunakan situasi yang mengandung konsep matematika dan nyata bagi siswa di dalam kehidupan sehari-hari siswa.

2. Fenomena pembelajaran (didactical phenomenology)

Situasi yang diberikan merupakan fenomena atau kejadian yang ada di sekitar kita yang dapat dijadikan bahan dan area aplikasi dalam pembelajaran matematika, dimana kejadian tersebut haruslah berangkat dari keadaan yang nyata bagi siswa sebelum mencapai tingkatan matematika secara formal. Dalam hal ini dua macam cara matematisasi haruslah dijadikan dasar untuk berangkat dari tingkat belajar matematika informal ke tingkat belajar matematika secara formal.

3. Model-model yang dibangun sendiri (self-developed models)

Peran model-model yang dibangun sendiri merupakan jembatan bagi siswa dari situasi nyata ke situasi konkrit atau dari informal ke formal matematika. Artinya siswa membuat model dalam menyelesaikan masalah. Pertama adalah model-of situasi yang dekat dengan alam pemikiran siswa dan di generalisasi menjadi mode-for situasi dalam formal matematika.

\subsubsection{Karakteristik Pembelajaran Matematika Realistik (PMR)}

Menurut Gravemeijer (Holisin, 2007, p. 47) disebutkan bahwa dari ketiga prinsip di atas, dioperasionalkan ke dalam lima karakteristik dari pendekatan PMR yaitu:

(1) Menggunakan masalah kontekstual (the use of contex)

Proses pembelajaran menggunakan pendekatan PMR, selalu diawali dengan masalah kontekstual, tidak dimulai dari sistem formal. Masalah kontekstual yang digunakan merupakan masalah sederhana yang dikenal oleh siswa. Masalah kontekstual dapat berupa realita atau sesuatu yang dapat dibayangkan oleh siswa.

(2) Menggunakan model (use models, bridging by verti instruments)

Penggunaan model, skema, diagram, simbol dan sebagainya merupakan jembatan bagi siswa dari situasi konkrit menuju abstrak. Siswa diharapkan mengembangkan model.

(3) Menggunakan kontribusi siswa (student contribution)

Dalam menyelesaikan masalah, siswa mempunyai kesempatan untuk menemukan cara pemecahan masalah dengan atau tanpa bantuan guru. Proses ini menunjukan bahwa pemecahan masalah merupakan hasil konstruksi dan produksi siswa sendiri. Dengan kata lain, dalam PMR kontribusi siswa sangat diperhatikan.

(4) Interaktivitis (interactivity)

Proses mengkonstruksi dan memproduksi pemecahan masalah tentu tidak dapat dilakukan sendiri. Untuk itu perlu interaksi baik antar siswa dengan guru, maupun siswa dengan siswa.

(5) Terintegrasi dengan topik lainnya (intertwining)

Struktur dan konsep matematika saling berkaitan, oleh karena itu keterkaitan antar topik harus digali untuk mendukung pembelajaran yang lebih bermakna.

\subsubsection{Langkah-langkah Pembelajaran Matematika Realistik (PMR)}


Berdasarkan prinsip dan karakteristik PMR, maka langkah-langkah yang harus dilakukan dalam kegiatan ini ini proses pembelajaran menurut De Lange (Holisin, 2007, p. 47) adalah sebagai berikut:

(1) Memahami masalah kontekstual

Pada langkah ini siswa diberi masalah kontekstual dan siswa diminta untuk memahami masalah kontekstual yang diberikan. Langkah ini tergolong dalam karakteristik-1 dari PMR.

(2) Menjelaskan masalah kontekstual

Pada langkah ini guru menjelaskan situasi dan masalah dengan memberikan petunjuk atau saran sperlunya terhadap bagian tertentu yang belum dipahami siswa. Langkah ini tergolong dalam karakteristik-4 dari PMR.

(3) Menyelesaikan masalah kontekstual

Setelah memahami masalah, siswa menyelesaikan masalah kontekstual secara individual dengan cara mereka sendiri, dan menggunakan perlengkapan yang sudah mereka pilih sendiri. Sementara itu guru memotivasi siswa agarsiswa bersemangat untuk menyelesaikanmasalah kontekstual dengan cara merekasendiri. Langkah ini tergolong dalam karakteristik-2 dalam PMR.

(4) Membandingan dan mendiskusikan jawaban

Guru menyediakan waktu dan kesempatan kepada siswa untuk membandingkan jawaban soal secara berkelompok, untuk selanjutnya dibandingkan dan didiskusikan di kelas. Di sini siswa dilatih untuk belajar mengemukakan pendapat. Langkah ini tergolong dalam karakteristik-3 dan karakteristik-4 dari PMR, yaitu menggunakan kontribusi siswa dan adanya interaksi antar siswa.

(5) Menyimpulkan

Setelah selesai diskusi kelas, guru membimbing siswa untuk mengambil kesimpulan suatu konsep atau prinsip. Langkah ini tergolong dalam karakteristik-4 dari PMR, yaitu interaksi antara siswa dan guru.

\subsubsection{Kelebihan dan Kelemahan pendekatan PMR}

a. Menurut Swarsono (Ningsih, 2014, p. 83) kelebihan dari pendekatan PMR adalah sebagai berikut :

1. Pendekatan PMR memberikan pengertian yang jelas dan operasional kepada siswa tentang keterkaitan antara matematika dengan kehidupan sehari-hari dan tentang kegunaan matematika pada umumnya.

2. Pendekatan PMR memberikan pengertian yang jelas dan operasional kepada siswa bahwa matematika adalah suatu bidang kajian yang dapat dikonstruksi dan dikembangkan sendiri oleh siswa dan oleh setiap orang "biasa" yang lain, tidak hanya oleh mereka yang disebut pakar dalam bidang tersebut.

3. Pendekatan PMR memberikan pengertian yang jelas dan operasional kepada siswa bahwa cara penyelesaian suatu soal atau masalah tidak harus tunggal, dan tidak harus sama antara satu orang dengan orang yang lain.

4. Pendekatan PMR memberikan pengertian yang jelas dan operasional kepada siswa bahwa dalam mempelajari matematika, proses pembelajaran merupakan suatu yang utama dan untuk mempelajari matematika orang harus menjalani sendiri proses itu dan berusaha untuk menemukan sendiri konsep-konsep dan materi-materi matematika yang lain dengan bantuan pihak lain yang sudah tahu 
(guru). Tanpa kemauan untuk menjalani sendiri proses tersebut, pembelajaran yang bermakna tidak akan terjadi.

5. Pendekatan PMR memadukan kelebihan-kelebihan dari berbagai pendekatan pembelajaran lain yang juga diangga "unggul".

6. Pendekatan PMR bersifat lengkap (menyeluruh), mendetail, dan operasional. Proses pembelajaran topik-topik matematika dikerjakan secara menyeluruh, mendetail, dan operasional sejak dari pengembangan kurikulum, pengembangan didaktiknya di kelas, yang tidak hanya secara makro tapi juga secara mikro berserta proses evaluasinya.

b. Selain kelebihan-kelebihan seperti yang diungkapkan di atas, terdapat juga kelemahan-kelemahan pendekatan PMR oleh Suwarsono (Ningsih, 2014, p. 84) adalah sebagai berikut:

1. Pemahaman tentang pendekatan PMR dan pengimplementasian pendekatan PMR membutuhkan paradigma, yaitu perubahan pandangan yang sangat mendasar mengenai berbagai hal, misalnya seperti siswa, guru, peranan sosial, peranan kontek, peranan alat peraga, pengertian belajar dan lain-lain. Perubahan paradigma ini mudah diucapkan tetapi tidak mudah untuk dipraktekkan karena paradigma lama sudah begitu kuat dan lama mengakar.

2. Pencarian soal-soal yang kontekstual, yang memenuhi syarat-syarat yang dituntut oleh pendekatan PMR tidak selalu mudah untuk setiap topik matematika yang perlu dipelajari siswa, terlebih karena soal tersebut masing-masing harus bisa diselesaikan dengan berbagai cara.

3. Upaya mendorong siswa agar bisa menemukan cara untuk menyelesaikan tiap soal juga merupakan tantangan tersendiri.

4. Proses pengembangan kemampuan berpikir siswa dengan memulai soal-soal kontekstual, proses matematisasi horizontal dan proses matematisasi vertikal juga bukan merupakan sesuatu yang sederhana karena proses dan mekanisme berpikir siswa harus diikuti dengan cermat agar guru bisa membantu siswa dalam menemukan kembali terhadap konsep-konsep matematika tertentu.

5. Pemilihan alat peraga harus cermat agar alat peraga yang dipilih bisa membantu proses berpikir siswa sesuai dengan tuntutan pendekatan PMR.

6. Penilaian (assesment) dalam pendekatan PMR lebih rumit dari pada pembelajaran konvensional.

7. Kepadatan materi pembelajaran dalam kurikulum perlu dikurangi secara substansial, agar proses pembelajaran siswa bisa berlangsung sesuai dengan prinsi-prinsip pendekatan PMR.

\subsubsection{Teori Belajar yang Melandasi Pembelajaran Matematik Realistik (PMR)}

a. Teori Ausubel

David Ausube (Ningsih, 2014, p. 85) mengelompokan belajar menjadi dua dimensi. Dimensi pertama, berhubungan dengan cara informasi atau materi pelajaran disajikan kepada siswa, melalui penerimaan atau penemuan. Dimensi kedua, menyangkut cara bagaimana siswa dapat mengaitkan informasi tersebut pada struktur kognitif yang telah ada.

Pada tingkat pertama, belajar penerimaan (reception learning) menyangkut materi dalam bentuk final, sedangkan belajar penemuan (discovery learning) yang mengharuskan siswa untuk menemukan sendiri sebagian atau seluruh materi yang dipelajari. 
Pada tingkat kedua, siswa menghubungkan atau mengaitkan informasi tersebut pada konsep-konsep dalam struktur kognitifnya, dalam hal ini "belajar bermakna (meaningful learning). Tetapi siswa mungkin saja tidak mengaitkan informasi tersebut pada konsep-konsep yang ada dalam struktur kognitifnya; siswa hanya terbatas menghafal informasi baru tersebut; dalam hal ini terjadi belajar hapalan (rote learning).

Pada pembelajaran matematika realistik, karakteristik pertama yaitu menggunakan masalah konstektual yang berfungsi sebagai motivasi awal atau starting point dalam pembelajaran, guru meminta kepada siswa untuk mengguakan strategi atau cara mereka sendiri dalam memecahkan masalah. Untuk keperluan tersebut siswa harus mampu menghubungkan pengetahuan yang dimiliki dengan permasalahan yang dihadapi. Bila pengetahuan/ konsep yang dimiliki siswa belum dapat digunakan dalam memecahkan masalah, maka guru perlu membimbing siswa (bersifat terbatas) dalam menemukan konsep tersebut. Dengan demikian siswa akan mampu menyelesaikan masalah konstektual yang diajukan kepadanya apabila ia memiliki cukup pengetahuan yang terkait dengan masalah tersebut.

Dari uraian ini, maka yang melandasi diberikan dari teori belajar bermakna Ausubel untuk pembelajaran matematika realistik adalah kemampuan siswa dalam menghubungkan pengetahuan yang ada dengan masalah konstektual yang sedang dibahas. Kemampuan ini akan sangat membantu dalam menyelesaikan masalah yang dihadapi.

b. Teori Piaget

Teori Piaget sering disebut sebagai genetic epistemology (epistemologi genetik) karena teori ini berusaha melacak perkembangan kemampuan intelektual menurut Hergenhahn dan Olson (Ningsih, 2014, p. 86) . Menurut Piaget (dalam Makmur Sugeng, 2004: 26), perkembangan intelektual didasarkan pada dua fungsi, yaitu organisasi dan adaptasi. Organisasi memberikan organisme kemampuan untuk mengorganisasikan proses-proses fisik atau psikologi menjadi sistem-sistem yang teratur dan saling berhubungan. Sedangkan adaptasi yang dimaksud adalah adaptasi terhadap lingkungan.

Teori Piaget ini memberikan beberapa implikasi dalam pembelajaran, yaitu:

1. Memusatkan perhatian pada proses berfikir anak, tidak sekedar pada hasilnya

2. Menekankan pada pentingnya peran siswa dalam berinisiatif sendiri dan keterlibatannya secara aktif dalam pembelajaran

3. Memaklumi adanya perbedaan individual dalam hal kemajuan perkembangan

Berdasarkan teori Piaget, pendekatan PMR dalam kegiatan pembelajaran memfokuskan pada proses berpikir siswa, bukan sekedar pada hasil. Selain itu dalam pembelajaran ini mengutamakan peran siswa berinisiatif untuk menemukan jawaban dari soal konstektual yang diberikan guru dengan caranya sendiri dan siswa didorong untuk terlibat aktif dalam kegiatan pembelajaran untuk mengonstruksi atau menemukan konsep.

c. Teori Vygotsky

Teori Vygotsky menekankan pada hakekat sosio kultural pembelajaran, yaitu siswa belajar melalui interaksi dengan orang dewasa dan teman sebaya. Hal ini sesuai dengan yang dikemukakan oleh Cobb (Holisin, 2007, p. 48) Vygotsky menekankan pentingnya interaksi sosial dengan orang-orang yang lain terlebih yang punya pengetahuan lebih baik dan sistem yang secara kultural telah berkembang dengan baik. 
Ide penting lain yang dapat diambil dari teori Vygotsky (Ningsih, 2014, p. 88) adalah scaffolding yaitu pemberian sejumlah besar bantuan kepada seseorang siswa selama tahap awal pembelajaran dan kemudian siswa tersebut mengambil alih tanggung jawab yang semakin besar segera setelah ia dapat melakukannya. Bantuan tersebut dapat berupa petunjuk, peringtan atau dorongan yang memungkinkan siswa tumbuh sendiri. Scaffolding dapat diartikan sebagai pemberian sejumlah bantuan kepada seorang siswa selama tahap-tahap awal pembelajaran dan kemudian mengurangi bantuan tersebut dan memberikan kesempatan kepada siswa untuk mengambil alih tanggungjawab yang semakin besar setelah ia dapat melakukannya. Scaffolding merupakan bantuan yang diberikan kepada siswa untuk belajar dan untuk memecahkan masalah. Bantuan tersebut dapat berupa petunjuk, dorongan, peringatan, menguraikan masalah ke dalam langkahlangkah pemecahan, memberikan contoh, dan tindakan-tindakan lain yang memungkinkan siswa itu belajar mandiri Ali (Rahmawati, 2013, p. 230).

Teori Vygotsky ini sejalan dengan karakteristik pembelajaran matematika realistik, yaitu, terdapat interaksi (interactivity) yang terus-menerus antara siswa yang satu dengan siswa lain, juga antar siswa dengan pembimbing (guru) dan siswa dengan perangkat pembelajaran sehingga setiap siswa mendapatkan manfaat positif dari interaksi tersebut. Hal ini terlihat di dalam kelompok (masing-masing kelompok 6 - 7 siswa) yang dirancang pada proses pembelajaran. Selain itu dalam pendekatan PMR bantuan yang diberikan guru hanya sebatas pada pertanyaan-pertanyaan siswa di awal pemecahan masalah konstektual yang diberikan pembimbing (guru), dengan memberikan petunjuk atau saran sampai siswa mengerti dengan maksud soal.

d. Teori Bruner

Menurut Bruner (Ningsih, 2014, p. 89) belajar matematika ialah belajar tentang konsep-konsep dan struktur-struktur matematika yang terdapat dalam materi yang dipelajari serta mencari hubunan-hubungan antara konsep-konsep dan struktur-struktur matematika itu. Pemahaman terhadap konsep dan struktur suatu materi menjadikan materi itu dipahami secara lebih komprehensif. Selain dari itu pengetahuan siswa lebih mudah diingat dan bertahan lama materi bila yang dipelajari mempunyai pola yang terstruktur. Dengan memahami konsep dan struktur akan mempermudah terjadinya transfer.

Bruner (Ningsih, 2014, p. 90) menggambarkan tiga tahap perkembangan siswa, yaitu:

1. Enactive, pada tahap ini siswa di dalam belajar menggunakan manipulasi objek-objek secara langsung.

2. Iconic, tahap ini menyatakan bahwa kegiatan siswa mulai menyangkut mental yang merupakan gambaran dari objek-objek.

3. Simbolic, pada tahap ini siswa memnipuasi symbol-simbol secara langsung dan tidak lagi ada kaitannya dengan objek-objek.

Berdasarkan teori Bruner, pendekatan PMR cocok dalam kegiatan pembelajaran karena di awal pembelajaran sangat dimungkinkan siswa memanipulasi objek-objek yang ada kaitannya dengan masalah kontekstual yang diberikan guu secara langsung. Kemudian pada proses matematisasi vertikal siswa memanipulasi simbol-simbol.

Dari uraian di atas dapat simpulkan bahwa teori belajar Ausubel, Piaget, Vygotsky dan Bruner sama-sama menekankan pada keaktifan siswa untuk mengkonstruksi atau membangun sendiri pengetahuan mereka sampai menemukan konsep, menekankan proses belajar terletak pada siswa sedangkan guru berfungsi sebagai pembimbing atau fasilitator, dan belajar ditekankan 
pada proses dan bukan hanya produk. Hal ini sejalan dengan prinsip karakteristik dari pendekatan PMR.

\section{Kesimpulan}

Berdasarkan pembahasan di atas, maka dapt diambil beberapa kesmipulan sebagai berikut.

1) Prinsip-prinsip dalam pendekatan PMR

a. Penemuan kembali dan permatematikaan progresif (guided reinvention and progressive mathematizing)

b. Fenomena pembelajaran (didactical phenomenology)

c. Model-model yang dibangun sendiri (self-developed models)

2) Karakteristik pendekatan PMR

a. Menggunakan masalah kontekstual (the use of contex)

b. Menggunakan model (use models, bridging by verti instruments)

c. Menggunakan kontribusi siswa (student contribution)

d. Interaktivitis (interactivity)

e. Terintegrasi dengan topik lainnya (intertwining)

3) Langkah-langkah pendekatan PMR

a. Memahami masalah kontekstual

b. Menjelaskan masalah kontekstual

c. Menyelesaikan masalah kontekstual

d. Membandingan dan mendiskusikan jawaban

e. Menyimpulkan

4) Kelebihan dan kekurangan pendekatan PMR

Kelebihan

a. Mengaitkan antara matematika dengan kehidupan sehari-hari dan tentang kegunaan matematika pada umumnya.

b. Mengkonstruksi pengetahuan dan dikembangkan sendiri oleh siswa.

c. Memberikan cara penyelesaian suatu soal atau masalah tidak harus tunggal, dan tidak harus sama antara satu orang dengan orang yang lain.

d. Dalam pembelajaran matematika realistik, siswa berusaha untuk menemukan sendiri konsep-konsep dan materi-materi matematika yang lain dengan bantuan pihak lain yang sudah tahu (guru).

e. Memadukan kelebihan-kelebihan dari berbagai pendekatan pembelajaran lain yang juga diangga "unggul".

f. Pendekatan PMR bersifat lengkap (menyeluruh), mendetail, dan operasional. Proses pembelajaran topik-topik matematika dikerjakan secara menyeluruh, mendetail, dan operasional sejak dari pengembangan kurikulum, pengembangan didaktiknya di kelas, yang tidak hanya secara makro tapi juga secara mikro berserta proses evaluasinya.

Kekurangan

a. Pengimplementasian pendekatan PMR membutuhkan paradigma yang sangat mendasar mengenai berbagai hal.

b. Pencarian soal-soal yang kontekstual, yang memenuhi syarat-syarat yang dituntut oleh pendekatan tidak selalu mudah untuk setiap topik matematika yang perlu dipelajari siswa.

c. Upaya mendorong siswa agar bisa menemukan cara untuk menyelesaikan tiap soal juga merupakan tantangan tersendiri.

d. Proses pengembangan kemampuan berpikir siswa dengan memulai soal-soal kontekstual, proses matematisasi horizontal dan proses matematisasi vertikal juga bukan merupakan sesuatu yang sederhana.

e. Pemilihan alat peraga harus cermat agar alat peraga yang dipilih bisa membantu proses berpikir siswa sesuai dengan tuntutan pendekatan PMR. 
f. Penilaian (assesment) dalam pendekatan PMR lebih rumit dari pada pembelajaran konvensional.

g. Kepadatan materi pembelajaran dalam kurikulum perlu dikurangi secara substansial, agar proses pembelajaran siswa bisa berlangsung sesuai dengan prinsiprinsip pendekatan PMR.

5) Teori Belajar yang Melandasi Pembelajaran Matematik Realistik (PMR)

a. Teori belajar Ausubel

b. Teori Piaget

c. Teori Vygotsky

d. Teori Bruner

\section{Referensi}

Afriansyah, E. A. (2016). Makna Realistic dalam RME dan PMRI. Lemma. https://doi.org/10.22202/j1.2016.v2i2.578 Al Jupri. (1998). Pendidikan Matematika Realistik : Sejarah, Teori, dan Implementasinya. Encyclopedia of Immunology. https://doi.org/10.1006/rwei.1999.0012

Freudenthal, H. (2006). Revisiting mathematics education (9th ed.). New York: Kluwer Academic Publisher.

Heuvel-Panhuizen, M. Van den. (2000). Mathematics education in the Netherlands : A guided tour. Freudenthal Institute Cd-Rom for ICME9, 1-32.

Holisin, I. (2007). Pembelajaran Matematika Realistik. Didaktis.

Ningsih, S. (2014). Realistic Mathematics Education: Model Alternatif Pembelajaran Matematika Sekolah. Jurnal Pendidikan Matematika, 1(2), 73. https://doi.org/10.18592/jpm.v1i2.97

Rahmawati, F. (2013). Pengaruh Pendekatan Pendidikan Realistik Matematika dalam Meningkatkan Kemampuan Komunikasi Matematis Siswa Sekolah Dasar. Junal FMIPA Unila, 1(1), 225-238.

Van den Heuvel-Panhuizen, M., \& Drijvers, P. (2014). Realistic Mathematics Education. In Encyclopedia of Mathematics Education. https://doi.org/10.1007/978-94-007-4978-8_170

Wahyudi. (2012). Pembelajaran Matematika Realistik Sebagai Sebuah Cara Mengenal Matematika Secara Nyata. 